\title{
Language and Emotion: The Communication Pattern on The Result of Central Jakarta Governor Election on Online Newspaper and Its Pedagogical Implications
}

\author{
Rahmawati Aprilanita ${ }^{1, *}$ \\ 1Graduate Program, Universitas Negeri Malang, East Java, Indonesia \\ *Correspondence: Graduate Program, Universitas Negeri Malang, East Java, Indonesia. E-mail: \\ aalchakim@gmail.com
}

Received: December 27, 2017

Accepted: January 11, 2018 Online Published: January 15, 2018

doi:10.5430/ijelt.v5n1p35

URL: https://doi.org/10.5430/ijelt.v5n1p35

\begin{abstract}
The present study aims at observing and presenting the types of language features used by Indonesian adults commenting on an online news using English as their foreign language to know whether Indonesians tend to be blunt or mitigate in expressing their feeling on the results of central Jakarta governor election. The comments uttered were their reaction and expression on the result of Central Jakarta Governor Election. The data observed was taken from all comments on a headline of online newspaper. The comments were from 74 people. The findings are generated based on quantitative calculation on the major verb used to express the feelings.
\end{abstract}

Keywords: language, emotion, reading, direct, indirect

\section{Introduction}

The governor election of central Jakarta is interesting to be observed since it is the capital city of Indonesia. The language features uttered by Indonesian in their comments on the news related with the result of the election is interested to observe. It reflects how Indonesians express their emotion; excited or disappointed with the result. James C. Wilce (2009) suggests "The loci of emotion in language are as numerous as locusts in a plague: phonology and sound symbolism, morphological processes (including reduplication), lexicon, syntax, discourse structure. Affect also emerges in the emergent text-like, even poetic, features of discourse, and in the relation of utterance or text to context." Hence the comments uttered on the online newspaper taken and treated as a text.

The language used is also said can be used as a tool to identify personality. By seeing the dictions used in the utterances whether they tend to be direct or indirect in expressing their emotion to words that describes feelings. The indirect interaction through online media has promoted individuals in more straightforward expressing their feelings and opinion than in direct communication (face to face). The degree of straightforwardness can be seen from the comments on national online newspaper such as the Jakarta Post. By accumulating the data entry, the result can be generated then the following research questions can be answered:

a. Do people tend to be direct or indirect in expressing their feeling and opinion on social media?

b. Why do people tend to be direct or indirect in expressing their feeling on social media?

\section{Theoretical Framework}

\subsection{Language and Emotion}

The language and emotion relation according to Wilce (2009) is the emotion felt by person is talking and translated subjectively into words. The translation of emotion into words of the speaker's current emotions is descriptive on the surface but it shares universal performatives structure by using first person and present tense. The reason is according to Reddy (2001) calls these first person present-tense feeling statements emotives. Along with other inputs from within and without, the emotives themselves become involved in cognitive-emotional activation and translation. 
Uttering an emotive may cause an increase in activation of the emotions named; in others the emotive backfires, causing increased awareness of "translation" and navigation problems, highlighting the never-quite-manageable flow of emotion in relation to social demands. Furthermore, Reddy (2001) has classified the language component involved in expressing emotion into the following:

- The lexicon is where many analyses of emotion in language begin and end.

- Formal grammar, verb mood may appear to have little to do with emotional mood. Mood or modality is a grammaticalized means of expressing speaker stance toward his or her proposition.

- Mirror neurons might well be the enablers of our earliest forms of empathy and intersubjectivity - feeling with another body's parts such as bodies, mouths, eyes, ears, etc in form of semiotic which are common in social space.

\subsection{Language, Emotion and Cognition}

In relation to emotion and cognition, William Reddy (2001) defines emotions as "goal-relevant activations of thought material that exceed the translating capacity of attention within a short time horizon." From his explanation we can get the idea that emotion is related to attention in a particular time and the span in short. Thus, we may say that emotion is contextual. Therefore, to understand how emotion can produce right word to be uttered in describing precise feelings, we can refer to Reddy's formulation of "activation" and "translation" (Reddy, 2001) in which those terms are borrowed from cognitive psychology.

According to Reddy (2001), activation is a state that renders thoughts and other inputs available for processing. Full activation enables sustained attention. Translation means, everything that we pay attention to whether it is perceptual inputs of various sorts, it requires various sorts of translation from sensory "codes" into linguistic codes. When engaging in emotion talk, we attend closely not only to inner feelings but to others' reactions. Emotion talk translates subjectivities into words. Another explanation related to emotion and language processing is proposed by Lindquist et.al (2015).

Lindquist et.al (2015) argues that language helps individuals use concepts to make meaning of on-going sensory perceptions. Building on this evidence, they outline predictions from a psychological constructionist model of emotion in which language serves as the "glue" for emotion concept knowledge, binding concepts to embodied experiences and in turn shaping the ongoing processing of sensory information from the body and world to create emotional experiences and perceptions. According to the psychological constructionist conceptual act theory (ACT), an instance emotion occurs when information from one's body of other people's bodies is made meaningful in light of the present situation using concept knowledge about emotion. The CAT suggests that language plays a role in emotion because language supports the conceptual knowledge used to make meaning of sensations from the body and world in a given context.

\subsection{Previous Researches}

The previous researches related to media, rhetorical study and discourse analysis have tried to discover the relationship between language and emotion. One of the researches concern about the role of language in emotion from psychological constructionism. This research was conducted by Lindquist et.al (2016) by referring to psychological constructionist Conceptual Act Theory (CAT) findings which states that language is a fundamental element in emotion that is constitutive of both emotion experience and perceptions. The emotion occurs when information from present situation is conformed to the concept knowledge about emotion. Language helps human to use its concepts to create meaning of the happening sensory perceptions. For multilingual speakers the researches find that they experience less emotional reactivity. The different languages possessed by the speakers denote different emotion categories that promote different emotion regulation.

The next study concerns about the styles of social media campaigning and influence in a hybrid political communication system by Karlsen and Enjolras (2016) which took place in Norwegia. The social media was chosen is twitter. The research focused on the way the political candidates in campaigning through social media twitter and the influence. The findings showed that social media is playing significant role in the Norwegian campaign. The use of social media by the candidates was divided into two types: a party-centered and individualized social media style. The candidate who concerned with their candidacy tends to have individualized style and the result was they were not successful and influential since they only showed their individual creativity without strengthening their party platform. Meanwhile the successful candidates is the ones who could synergize between traditional media channel and social media. The interaction in both media was found to contribute in gaining influence. 
The next study on social media was conducted by Viorica Paus (2013). She concerned about new media and leadership: social media and open organizational communication whose aim is to identify and analyze the extent to which new media have penetrated the Romanian organizations' internal communication and have influenced the leadership. The research found that the use of new media as a means of communication within the organization increases the bottom up- feedback and it increases self-esteem and confidence of the employees since flattens the hierarchy structures and create personalized-relationship between the management and employees thus the leaders can gain greater visibility and transparent management decisions.

\section{Methodology}

The method employed in conducting the research is semantics analysis design which allows the readers to interpret the text. Then categorizing the comments into two categories: direct and indirect. The data entry was calculated to generate the result. The result shows the answer to the research questions.

\subsection{Data Collection Method}

The comments taken from the comments column of the Jakarta Post. The comments are analyzed based on the words used by the writers to express their feelings and opinion whether it is directly stated their feelings such as sad, bad, congratulation, etc. The word categorization based on the directness and indirectness word chosen to express feelings, emotion and thoughts.

\subsection{Data Analysis}

The result of categorization will be analyzed based on lexical and structural form then counted and generated to answer the research questions.

\section{Research Findings and Discussion}

The result of the data analysis findings can be summarized as follows:

Table 1. The Total Comments

\begin{tabular}{lcccc}
\hline Total commenters & $\begin{array}{c}\text { The grammatical } \\
\text { structure used }\end{array}$ & $\begin{array}{c}\text { The firs-person } \\
\text { pronoun }\end{array}$ & Direct & Indirect \\
\hline 74 commenters & Present tense & 6 & 53 & 21 \\
\hline
\end{tabular}

From the above table we can see that people tend to be more direct in expressing their feelings on the online newspaper even though the issues is sensitive, politics and religion. The indirect interaction urges people to freely express their ideas without any fear. Will (2014) argues that social media isn't a process of creative writing at least not in the traditional sense, it's a fast and convenient way of interacting with an audience. Indeed, the directness in expressing feelings because people feel more convenient interacting with other audiences. They do not have to meet face to face or know each other to comment. They are not afraid of direct verbal of physical attack if their comments contradicts to each other. According to Wilce (2009) in stating emotion, the speakers tend to use first-person style and in present tense structure as universal structure in expressing current feeling. It is because according to Reddy (2001) cognitive-emotional activation and translation which change instantly when people feel the emotion and utter it based on their language reference they have. Somehow, from the data taken above, we can see that the speakers do not use pronoun but directly uttered what they feel about the election result. The structure used in all comments mostly in present tense. Present tense is employed as the simple and direct way to express feelings. It finds to be more representative in expressing their feelings and thoughts.

Second about the lexicon the commenters used to express their feeling (emotion) and thought over the governor election result showed that no cursing or offensive words there. Psychological constructionist conceptual act theory (ACT), an instance emotion occurs when information from one's body of other people's bodies is made meaningful in light of the present situation using concept knowledge about emotion. Somehow the multilingual speakers differ in expressing the emotion in other language. According to Lindquist et al (2015) multilingual speakers the researches find that they experience less emotional reactivity. The different languages possessed by the speakers denote different emotion categories that promote different emotion regulation. Social media changes the interpersonal communication style. As we can see from the above calculation table of comments on online newspaper that people 
tend to be direct in expressing their feelings and describing their thought.

\subsection{Social Media as Mediated Space of Personal to Public}

The change of interpersonal communication style from private to public space can be seen as identity shift. Hence, we may refer to Wilce (2009) to investigate identification processes is to ask about social, semiotic, and psychodynamic complexity, rather than the apparent fixity of 'identities.' The words employed to express a certain emotion also depends on the context, here is the media. The indirect communication promotes the speakers to be more expressive and blunt. In relating to social media as plural communication forum Wilce (2009) suggests that particular linguistic acts showing emotion, and mass social movements encouraging and evoking passion toward linguistic code and identify moments. Hence the response or interpretation of each words or sentences uttered by commenters to this DKI Governor's election result cannot be estranged from the society's common knowledge and understanding about the word meaning.

Karlsen and Enjolras (2016) contends that it is potentially, because social media allows decentralized and content-free production and diffusion, the hybrid media system may change the relations of power between actors involved in an interaction than in the real life communication (face-to-face communication). Their argument is based on their findings about social media rule in Norwegian political campaign. The findings confirm that social media is an essential and integrated part of the emerging hybrid political communication system used by politicians and show that this hybrid communicative structure can be used to gain influence in party politics (Karlsen \& Enjolras, 2016).

In relation to interpersonal communication and its effect on the personal relation in daily life we can refer to Paus (2013) findings on how social media used and effected Romanian organizational internal communication. Paus (2013) social media is favored as the emergence of informal leaders who influence individual messages and lead to the structuring of group views; also the use of social networking and the attraction of a large number of 'friends' can lead to the discovery of the structure leading to the person concerned and it disappears inhibitions in front of the hierarchy by the fact that it can mask identities and thereby become more honest opinions and more virulent. Meanwhile Indonesian as Foreign language speakers who are also considered as bilinguals according to Paus (2015), bilinguals experience less emotional reactivity. The different languages possessed by the speakers denote different emotion categories that promote different emotion regulation. As English foreign language speakers, Indonesians do not have as much as vocabulary to express their feelings freely like native speakers. It because Indonesians do not share the common idea about the emotion-semantics words.

\subsection{Reading and Emotion}

Reading the headline of the Jakarta Post about the result of the center Jakarta Governor's election arouse a certain emotion inside of the readers. Kweldju (2015) suggest that reading is an activity that interconnect among cognition, emotion, memory and physiology. It also triggers them to comment based on what they thought as their reaction toward the result. The emotion which is regulated by limbic system. Furthermore, Kweldju (2015) explains that the limbic system regulates memory and emotion is closely related to hypothalamus and brainstem nuclei that link among emotion, cognition and memory. The emotion during reading the news is not only processed by limbic system but also the right hemisphere for semantic relationship with emotional states that happens on the fixation during reading that promote the selection of the English words used in the comment on the online newspaper headline which involves sensory data and stored memory. (Kweldju, 2015).

\subsection{Pedagogical Implications}

This research gives us reflection of the importance of teaching the students about politeness related to speaking to public. English as Foreign Language in Indonesia makes the students must understand about cultural gaps that the students should aware. Therefore, the teacher should include politeness across culture into their teaching and learning process including designing syllabus, lesson plan and selecting material.

\section{Conclusion}

From the findings we can conclude that in expressing emotion on social media on English printed newspaper in Indonesia, as English Foreign language speakers, people tend to use present tense without using first-speaker style in uttering their feelings and without any offensive and cursing words. Some factors can be derived to explain the findings: the structure and the bilingualism. The language uttered to express emotion depends largely on the experience and knowledge of words related to emotion as what Reddy (2001) called as mirror neurons. The way people express their feeling is preferably in first person pronoun and in present tense since it can show the direct 
expression, highlight the emotion expressed and easily meet the society understanding and knowledge of that emotion. As bilinguals, the direct style in uttering their emotion do not make them to use any offensive or cursing words. According to Paus (2015), bilinguals experience less emotional reactivity. The different languages possessed by the speakers denote different emotion categories that promote different emotion regulation. Hence, the commenters neither use cursing nor offensive words like Americans or British do since they do not have the same shared-word in expressing emotion. The emotion words are standard; so sad.

\section{References}

Karlsen, R., \& Enjolras, B. (2016). Styles of Social Media Campaigning and Influence in a Hybrid Political Communication System: Linking Candidate Survey Data with Twitter Data. The International Journal of Press/Politics, (Online), 21(3), 338-357. https://doi.org/10.1177/1940161216645335

Kweldju, S. (2015). Neurobiology Research Findings: How the Brain Works During Reading. PSSA, 50, 125-142.

Lindquist, K. A., MacCormark, J. K., \& Shablack, H. (2015). The Role of Language and Emotion Predictions from Psychological Constructionism. Frontiers in Psychology, 6(444), 1-17. https://doi.org/10.3389/fpsyg.2015.00444

Paus, Viorica. (2013). New Media and Leardership: Social Media and Open Organizational Communication. Change and Leadership. Retrieved April 24 $4^{\text {th }}, 2017$ from http://manager.faa.ro/download/719_1708.pdf

Reddy, William M. (2001). The Navigation of Feeling: A Framework for the History of Emotions. Cambridge, New York: Cambridge University Press. https://doi.org/10.1017/CBO9780511512001

Wil. (2014). Has Social Media Changed The Way We Speak and Write English? Retrieved April $26^{\text {th }}$, 2017 from https://englishlive.ef.com/blog/has-social-media-changed-the-way-we-speak-and-write-english/

Wilce, J.M. (2009). Language and Emotion. New York: Cambridge University Press. https://doi.org/10.1017/CBO9780511626692

\section{Appendix 1.}

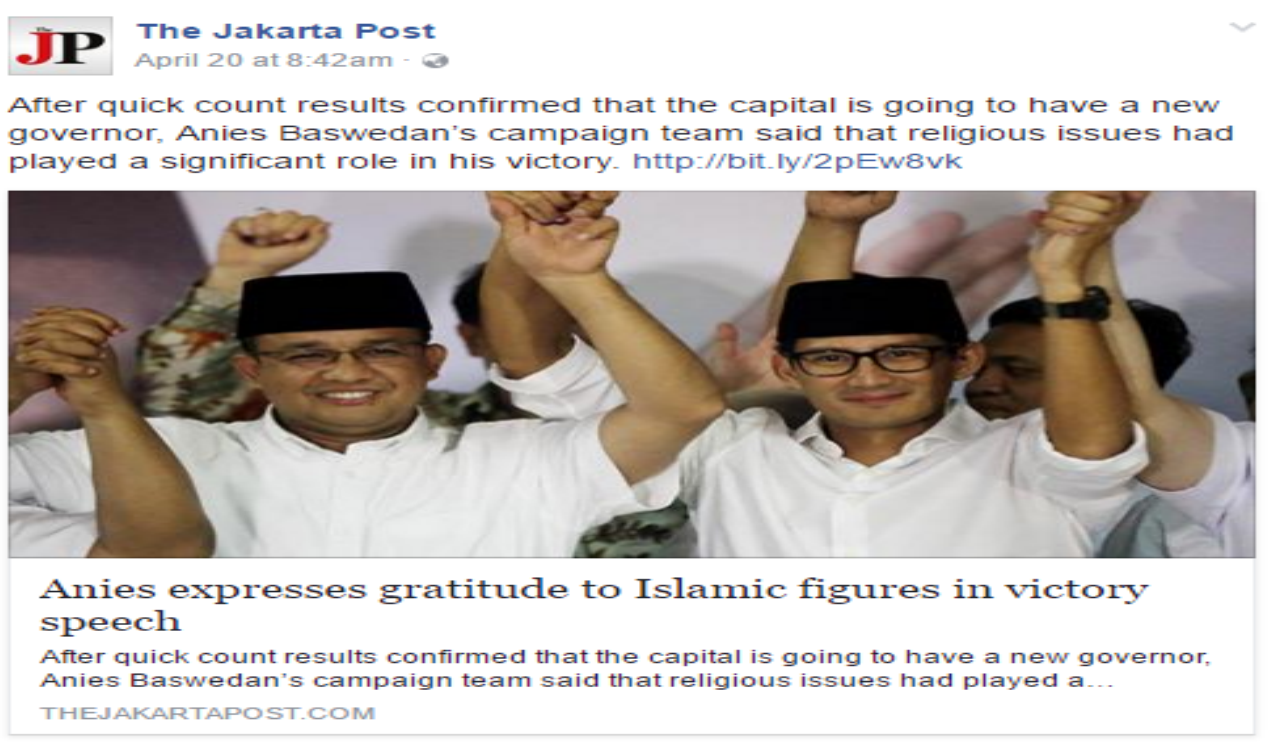




\section{Appendix 2.}

\begin{tabular}{|c|c|c|c|c|}
\hline NO & $\begin{array}{l}\text { ACCOUNT } \\
\text { NAMES }\end{array}$ & LEXICAL USED & DIRECT & $\begin{array}{l}\text { INDIREC } \\
T\end{array}$ \\
\hline 1 & $\begin{array}{l}\text { Nikolov } \\
\text { Nicholovski }\end{array}$ & of course! & $\mathrm{V}$ & \\
\hline 2. & Bro Die & What a joke. & $\mathrm{V}$ & \\
\hline 3 & $\begin{array}{l}\text { Glenn } \\
\text { Lenoir } \\
\text { Kamal }\end{array}$ & Shame on them. & $\mathrm{V}$ & \\
\hline 4 & $\begin{array}{ll}\text { Ian } & \text { A } \\
\text { Reddish } & \end{array}$ & So now the truth comes out. & & V \\
\hline 5 & $\begin{array}{l}\text { Amira } \\
\text { Scipione }\end{array}$ & $\begin{array}{l}\text { So, they are elected based on religion and nasi bungkus } \\
\text { not competences... }\end{array}$ & & $\mathrm{v}$ \\
\hline 6 & $\begin{array}{ll}\text { Mikal } & \text { R } \\
\text { Neff }\end{array}$ & $\begin{array}{l}\text { I think any candidate who didn't publicly denounce the } \\
\text { bullying by extremists should be considered unfit to } \\
\text { govern such a diverse city as Jakarta. }\end{array}$ & & $\mathrm{v}$ \\
\hline 7 & $\begin{array}{l}\text { Harry } \\
\text { Dinsmore }\end{array}$ & Truer words were never spoken !!!! & & $\mathrm{v}$ \\
\hline 8. & Yessi Wid & OF COURSE!! & $\mathrm{V}$ & \\
\hline & $\begin{array}{l}\text { David Ben } \\
\text { Yeshua }\end{array}$ & $\begin{array}{l}\text { Use God name to commit sin. You going to hell after you } \\
\text { died Anies }\end{array}$ & $\mathrm{v}$ & \\
\hline 9. & $\begin{array}{l}\text { Nursrita } \\
\text { Reeta }\end{array}$ & $\begin{array}{l}\text { It is sad that the election of the governor bcause of } \\
\text { religious, racial and sara issuea that are brought, and not } \\
\text { bcause of the real work of the governor of ahok who is } \\
\text { judged. }\end{array}$ & $\mathrm{v}$ & \\
\hline 10. & $\begin{array}{l}\text { Handoko } \\
\text { Suwono }\end{array}$ & $\begin{array}{l}\text { I believe a big golden mosque will soon be built in Jakarta } \\
\text { at three times the budget of real cost! }\end{array}$ & & $\mathrm{v}$ \\
\hline 11. & Kandi Sofia & $\begin{array}{l}\text { Sad day for multiculturalism in Indonesia. Indeed. } \\
\text { What a cowardly victory. Now that they won, they } \\
\text { thanked "Islamic figures"', like Rizieq? }\end{array}$ & $\mathrm{v}$ & \\
\hline 12. & Jessica Ali & $\begin{array}{l}\text {..this only shows Anies will be in control over the } \\
\text { conservatives. }\end{array}$ & $\mathrm{v}$ & \\
\hline 13. & Dan Ahmad & $\begin{array}{l}\text { Congratz..!!! They have won by KO and Jakarta will be } \\
\text { better }\end{array}$ & $\mathrm{v}$ & \\
\hline 14. & Yan Tirta & $\begin{array}{l}\text { Again we are not bitter cause he lost. We are bitter the } \\
\text { hopes of the many, the hopes of Bhinneka Tunggal Ika, } \\
\text { the hopes of the people lost yesterday. }\end{array}$ & $\mathrm{v}$ & \\
\hline 15. & $\begin{array}{l}\text { Charles } \\
\text { Jarret }\end{array}$ & Exactly. The Islamic agenda will continue. & $\mathrm{v}$ & \\
\hline
\end{tabular}




\begin{tabular}{|c|c|c|c|c|}
\hline 16. & Banani & $\begin{array}{l}\text { Sit back and see how they work on their promises, } \\
\text { Preferably with popcorn. }\end{array}$ & & $\mathrm{v}$ \\
\hline 17. & $\begin{array}{l}\text { Johannes } \\
\text { Bambang } \\
\text { Wirawan }\end{array}$ & $\begin{array}{l}\text { Of Course, Anies expresses its gratitude becase most } \\
\text { Muslims think that Ahok has the soul of Partai Komunis } \\
\text { Indonesia (Indonesia Communist Party) which it actually } \\
\text { disbanded on } 12 \text { March } 1966 \text { by the Military General } \\
\text { Soeharto. }\end{array}$ & $\mathrm{v}$ & \\
\hline 18. & $\begin{array}{l}\text { Rumi } \\
\text { Raniri }\end{array}$ & JIC if Anies-Sandi actually screw up & $\mathrm{v}$ & \\
\hline 19. & Björn Giese & $\begin{array}{l}\text { So finally they publicly admit the obvious - that their } \\
\text { campaign was built on SARA issues. }\end{array}$ & $\mathrm{v}$ & \\
\hline 20. & $\begin{array}{l}\text { Melissa } \\
\text { Camelia }\end{array}$ & We'll see if his simple "thank you" is enough & & $\mathrm{v}$ \\
\hline 21. & $\begin{array}{l}\text { Ronald } \\
\text { Hasman }\end{array}$ & $\begin{array}{l}\text { Quite a show Mr. Prabowo, you make yourself a fine } \\
\text { producer. Well played Mr. Rizieq the Terror, best } \\
\text { antagonist actor. And congratulation to both okay donkey } \\
\text { winner Mr. Anies and Uno. All of you really made my } \\
\text { day. I can't stop laughing } \because: P\end{array}$ & $\mathrm{v}$ & \\
\hline 22. & $\begin{array}{l}\text { Prajna } \\
\text { Paramita }\end{array}$ & $\begin{array}{l}\text { Start working and deliver your promise! First, people can } \\
\text { house without DP, seems you guys have banks under your } \\
\text { thumb } \rightarrow: 0\end{array}$ & $\mathrm{v}$ & \\
\hline 23. & $\begin{array}{l}\text { Rubby } \\
\text { Riesta }\end{array}$ & $\begin{array}{l}\text { Guurl, even Stevie Wonder can see it!! } \\
\text { disgusting to see one religion even a criteria to become a } \\
\text { Gov.? }\end{array}$ & $\mathrm{v}$ & \\
\hline 24. & $\begin{array}{l}\text { Gloria } \\
\text { Siregar }\end{array}$ & Time will let know the people manies bersandiwara & $\mathrm{v}$ & \\
\hline 25. & $\begin{array}{l}\text { Sukaria } \\
\text { Sun }\end{array}$ & Back to square Jakarta & $\mathrm{v}$ & \\
\hline 26. & $\begin{array}{l}\text { Doc Gordon } \\
\text { Freeman.. }\end{array}$ & $\begin{array}{l}\text { Makes me wanna puke to read that Rizieq \& Co are being } \\
\text { described as pillars of society... What a huge step } \\
\text { backwards }\end{array}$ & $\mathrm{v}$ & \\
\hline 27. & $\begin{array}{l}\text { Rathma } \\
\text { Soma }\end{array}$ & Seriously??? Argghhhh. Just prove a point. & $\mathrm{v}$ & \\
\hline 28. & $\begin{array}{l}\text { Ron } \\
\text { Summerwoo } \\
\text { d }\end{array}$ & $\begin{array}{l}\text { Religion should have nothing to do with being governor. } \\
\text { Wake up Indonesia it's the year } 2017 \text { ! }\end{array}$ & & $\mathrm{v}$ \\
\hline 29. & $\begin{array}{l}\text { Joanne } \\
\text { Suseto }\end{array}$ & $\begin{array}{l}\text { Just another small part of the bigger 'agenda' that started } \\
\text { in the } 7 \text { th century - to invade \& conquer. } \\
\text { That filtered into the then West Indies in the } 14 \text { th century } \\
\text { via India \& Arabia. }\end{array}$ & & $\mathrm{v}$ \\
\hline 30. & Rifai Arfan & $\begin{array}{l}\text { Mr Ahok, many people still count on you. Run for another } \\
\text { one. Jakarta fits Anies. }\end{array}$ & $\mathrm{v}$ & \\
\hline 31. & $\begin{array}{l}\text { Mohd } \\
\text { Azlimi Bin }\end{array}$ & $\begin{array}{l}\text { Is ok... Ahok lost. The seat of KPK awaits him... Than we } \\
\text { see who have the last laugh. People will ask for } 0 \% \text { DP on }\end{array}$ & $\mathrm{v}$ & \\
\hline
\end{tabular}




\begin{tabular}{|c|c|c|c|c|}
\hline & Yaakop & $\begin{array}{l}\text { housing as promised by these two clowns.. } 0 \% \text { DP in } \\
\text { Jakarta.. Wahaha.. }\end{array}$ & & \\
\hline 32. & $\begin{array}{l}\text { Rochelle } \\
\text { Shahfazli Ev } \\
\text { i Shahfaz }\end{array}$ & sad days & $\mathrm{v}$ & \\
\hline 33. & $\begin{array}{l}\text { James } \\
\text { Clark }\end{array}$ & $\begin{array}{l}\text { Indonesia will be worse off for this in the long run. There } \\
\text { is no place for religion in politics }\end{array}$ & $\mathrm{v}$ & \\
\hline 34. & $\begin{array}{l}\text { Budi } \\
\text { Setyawan }\end{array}$ & $\begin{array}{l}\text { Be careful with what you want, you might get it. I wish } \\
\text { you all the best pak ahok }\end{array}$ & & $\mathrm{V}$ \\
\hline 35. & $\begin{array}{l}\text { Adrian } \\
\text { Atmadja } \\
\text { Brennan }\end{array}$ & $\begin{array}{l}\text { Of course the issues had played a significant role in your } \\
\text { victory. And this is the proof that most of the voters }(58 \%) \\
\text { in the election are dumb enough to believe in the issues } \\
\text { that you and your allies use as a weapon to knock Ahok } \\
\text { down. Well played! You won because you played } \\
\text { dirty vilu vilu }\end{array}$ & $\mathrm{v}$ & \\
\hline 36. & $\begin{array}{l}\text { Astried } \\
\text { Silvanie }\end{array}$ & $\begin{array}{l}\text { If course! As long as he's MUSLIM. Indonesian so easy to } \\
\text { manipulate by politician }\end{array}$ & $\mathrm{v}$ & \\
\hline 37. & Indy Noir & $\begin{array}{l}\text { Religion > Literally anything else } \\
\text { Thanks to this result indon politicians will play up the } \\
\text { religion angle because they know indonesians are full of } \\
\text { degenerate religious plebs who can't think beyond the } \\
\text { concepts of blasphemy and sins. We deserve Anies-Sandi, } \\
\text { we never deserved a leader like Ahok, we're not worthy of } \\
\text { it. }\end{array}$ & $\mathrm{v}$ & \\
\hline 38. & $\begin{array}{l}\text { Krish } \\
\text { Ramos }\end{array}$ & Going backwards instead of moving forward. & $\mathrm{v}$ & \\
\hline 39. & $\begin{array}{l}\text { Vania } \\
\text { Florencia } \\
\text { Alberta }\end{array}$ & $\begin{array}{l}\text { I'll be having the last laugh when all of this spiralled } \\
\text { downwards, don't wail in regret when they screwed you } \\
\text { over by taking your kjp rights away to feed the endless } \\
\text { hunger of corruptors' belly. }\end{array}$ & $\mathrm{v}$ & \\
\hline 40. & $\begin{array}{l}\text { Londo Ron } \\
\text { van Zanden }\end{array}$ & Only religion counts???? How stupid you cam be & $\mathrm{v}$ & \\
\hline 41. & $\begin{array}{l}\text { Neil } \\
\text { Whitcombe }\end{array}$ & $\begin{array}{l}\text { The very fact that Aines acknowledges that religion has } \\
\text { played a significant part in his victory, shows that this is a } \\
\text { hollow form of democracy. How sad that people } \\
\text { somehow think that a sacked education minister can do a } \\
\text { better job than the current incumbent! Many muslims } \\
\text { acknowledge that Ahok is a good man, but could not bring } \\
\text { themselves to vote for a non-muslim. Sad day for Jakarta } \\
\text { and Indonesia! The country still has a lot to learn about } \\
\text { democracy. }\end{array}$ & $\mathrm{v}$ & \\
\hline
\end{tabular}




\begin{tabular}{|c|c|c|c|c|}
\hline 42. & $\begin{array}{l}\text { Andre } \\
\text { Wijaya }\end{array}$ & $\begin{array}{l}\text { Most of the senior politicians are not radicals, but with } \\
\text { their tolerance to radicals, you can expect more and more } \\
\text { discrimination and intimidation happen daily in small } \\
\text { scale. }\end{array}$ & & $\mathrm{V}$ \\
\hline 43. & $\begin{array}{l}\text { Lena } \\
\text { Hartanto }\end{array}$ & $\begin{array}{l}\text { Indonesia is a democratic country based on pancasila. No } \\
\text { islamic country }\end{array}$ & & $\mathrm{v}$ \\
\hline 44. & $\begin{array}{l}\text { Dolly } \\
\text { Haryono }\end{array}$ & $\begin{array}{l}\text { No wonder Anies and Sandy won,,, just look at the people } \\
\text { that backing them up. Prabowo and Hari Tanoe... shame } \\
\text { indo, whats the purpose of our Garuda symbols with } \\
\text { Bhinekka Tunggal Ika if fpi muslim gonna destroyed } \\
\text { other race and religion? }\end{array}$ & $\mathrm{v}$ & \\
\hline 45. & Agus Honor & $\begin{array}{l}\text { This is how indonesia was trumped due to greed and } \\
\text { corruption whilst using religion as a weapon! }\end{array}$ & $\mathrm{v}$ & \\
\hline 46. & $\begin{array}{l}\text { Geoffrey } \\
\text { Harley }\end{array}$ & He should not be proud of bigotry & $\mathrm{v}$ & \\
\hline 47. & Igor Hakim & $\begin{array}{l}\text { A sad day for Jakarta and probably we can't find another } \\
\text { Governor that as good as Ahok in the future. The worst } \\
\text { era begin, brace yourself }\end{array}$ & $\mathrm{v}$ & \\
\hline 48. & $\begin{array}{l}\text { Callum } \\
\text { Mackinnon }\end{array}$ & $\begin{array}{l}\text { He's confusing religiois issues with bullying, fanatics, } \\
\text { thuggery and fools... good luck Jakarta... you're going to } \\
\text { need it with this idiot running the place. }\end{array}$ & $\mathrm{V}$ & \\
\hline 49. & Mila Anisa & $\begin{array}{l}\text { \#shameonyoudirtypoliticians \#idontsehumanity\#idontse } \\
\text { edemocratics \#idontseeequality \#idontseequality }\end{array}$ & $\mathrm{v}$ & \\
\hline 50. & Feliza Finy & $\begin{array}{l}\text { Oh come on as long as there's Sila number one in } \\
\text { Pancasila... Religion will always play its part in this } \\
\text { country. }\end{array}$ & & $\mathrm{v}$ \\
\hline 51. & $\begin{array}{l}\text { Jevon } \\
\text { Susanto Orv } \\
\text { in Tritama }\end{array}$ & still cant get over of these shits man & $\mathrm{v}$ & \\
\hline 52. & $\begin{array}{l}\text { Tina } \\
\text { Lumbantor } \\
\text { uan }\end{array}$ & $\begin{array}{l}\text { It means he admitted that religious issues were the main } \\
\text { reasons behind the victory. What a shame }\end{array}$ & $\mathrm{v}$ & \\
\hline 53. & $\begin{array}{l}\text { Arvinda } \\
\text { Lubis }\end{array}$ & $\begin{array}{l}\text { Wake up Indonesia!! Religion has nothing to do with all } \\
\text { these goverment things!! Why you people are so } \\
\text { blind??? 2017, welcome to the new era, Jakarta are going } \\
\text { backwards. }\end{array}$ & $\mathrm{v}$ & \\
\hline 54. & $\begin{array}{l}\text { Mtroy } \\
\text { Kalalo }\end{array}$ & $\begin{array}{l}\text { Ahok is a gift for Indonesia. He's the man that the people } \\
\text { really can lean on. He'd fought for transparency, modern, } \\
\text { open mindedness, Unity In Diversity! and believing that it } \\
\text { leads towards a brighter future for their children - and }\end{array}$ & $\mathrm{v}$ & \\
\hline
\end{tabular}




\begin{tabular}{|c|c|c|c|c|}
\hline & & $\begin{array}{l}\text { their grandchildren too. Unfortunately the battle become } \\
\text { an unfair challange we don't deserve Ahok. We proud of } \\
\text { Ahok and he will imprinted in our hearts. }\end{array}$ & & \\
\hline 55. & $\begin{array}{l}\text { Sumiya Tus } \\
\text { Sholehah }\end{array}$ & $\begin{array}{l}\text { Iam waiting for Ahok in } \quad \text { KPK } \\
\text { field } 0 \text { Then, he can kill everyone who } \\
\text { wants to destroy this beloved Country! Ameen }\end{array}$ & & $\mathrm{v}$ \\
\hline 56. & Anton Quist & $\begin{array}{l}\text { Their only campaign issue was: 'I am Muslim and Ahok } \\
\text { is kafir, so vote for the Muslim.' Even though his religion } \\
\text { was Anies' only selling point instead of any personal } \\
\text { competencies or accomplishments, nobody seemed to } \\
\text { care about the lack of a clear Anies-Sandi vision for } \\
\text { Jakarta. So what's next for Jakarta? Nobody knows... }\end{array}$ & $\mathrm{V}$ & \\
\hline 57. & $\begin{array}{l}\text { Oen } \\
\text { Sutrisno }\end{array}$ & $\begin{array}{l}\text { Dumb people who cares .. Jakarta would never be like } \\
\text { great city in the world.. Not even like Singapore.... }\end{array}$ & $\mathrm{v}$ & \\
\hline 58. & $\begin{array}{l}\text { Steve } \\
\text { Křečik }\end{array}$ & He who pays the piper, calls the tune. & & $\mathrm{V}$ \\
\hline 59. & $\begin{array}{l}\text { Pikintoro } \\
\text { Pikin }\end{array}$ & $\begin{array}{l}\text { Trump's team did the same ... making Trump climb to the } \\
\text { top ... religious and racial issues played significant roles ... }\end{array}$ & $\mathrm{v}$ & \\
\hline 60. & $\begin{array}{l}\text { Ricky } \\
\text { Lynch }\end{array}$ & $\begin{array}{l}\text { Anies thanks the FPI , for his new job .. } \\
\text { Time for international companies to think about closing } \\
\text { their businesses and move to other Asian countries... }\end{array}$ & & $\mathrm{v}$ \\
\hline 61. & $\begin{array}{l}\text { Mia } \\
\text { AmaliaDwi }\end{array}$ & $\begin{array}{l}\text { Yup very Islamic. After their supporters drank booze to } \\
\text { celebrate his victory. Pffft }\end{array}$ & & $\mathrm{v}$ \\
\hline 62. & $\begin{array}{l}\text { Chan } \\
\text { Roberts }\end{array}$ & Muslims voted against pancasila. & $\mathrm{v}$ & \\
\hline 63. & $\begin{array}{l}\text { Wenny } \\
\text { Margaretha } \\
\text { Nusawakan }\end{array}$ & $\begin{array}{l}\text { Congrats to the new Governor with zero accomplishment, } \\
\text { fired from his position as a minister. Racism won. } \\
\text { Cowardice and Bigotry won. }\end{array}$ & $\mathrm{v}$ & \\
\hline 64. & $\begin{array}{l}\text { Vic } \\
\text { Cunningha } \\
\text { m }\end{array}$ & Dumber and Dumber now more corruption & $\mathrm{v}$ & \\
\hline 65. & $\begin{array}{l}\text { Nicolas } \\
\text { Keke } \\
\text { Adjignon }\end{array}$ & Wow, sounds promising for the future! D: & & $\mathrm{V}$ \\
\hline 66. & $\begin{array}{l}\text { Lennyfebe } \\
\text { Susilowati }\end{array}$ & $\begin{array}{l}\text { How do You know they are the best governor? They } \\
\text { never prove it, especially Anies. Are you looking at their } \\
\text { program is illogical. I am waiting they will give a house } \\
\text { with DP } 0 \gg \text { ithout any qualifications. Are you blind to see } \\
\text { it? we have to be objective and look at Ahok as person, }\end{array}$ & & $\mathrm{v}$ \\
\hline
\end{tabular}




\begin{tabular}{|c|c|c|c|c|}
\hline & & not his religion & & \\
\hline 67. & $\begin{array}{l}\text { Adam } \\
\text { Krumnikl }\end{array}$ & $\begin{array}{l}\text { This Anies victory just shows the way how it's gonna be } \\
\text { done in the years to come in Indonesia. Radical Islamists } \\
\text { won't run in any elections under own platform. They will } \\
\text { side behind a puppet like Anies, who will be later obliged } \\
\text { to cater to their wishes when elected. That is very } \\
\text { dangerous. }\end{array}$ & $\mathrm{v}$ & \\
\hline 68. & $\begin{array}{l}\text { Mandy } \\
\text { Mirahsari }\end{array}$ & sad & $\mathrm{v}$ & \\
\hline 69. & $\begin{array}{l}\text { Francis } \\
\text { Aung }\end{array}$ & $\begin{array}{l}\text { I don't call this a victory Anies, it wasn't your ability to } \\
\text { win this election without taking advantage on religious } \\
\text { matter. A true man will never take advantage on others } \\
\text { weaknesses. }\end{array}$ & $\mathrm{v}$ & \\
\hline 70 . & $\begin{array}{l}\text { Ardhie Eka } \\
\text { Putra }\end{array}$ & $\begin{array}{l}\text { Soon, they only focused on religious stuff instead of } \\
\text { technical problem in Jakarta. }\end{array}$ & & $\mathrm{v}$ \\
\hline 71. & $\begin{array}{l}\text { Barbara A } \\
\text { Mc } \\
\text { Cutcheon }\end{array}$ & $\begin{array}{l}\text { The whole world is moving towards a one world order. It's } \\
\text { prophesied in the Bible. Amen }\end{array}$ & & $\mathrm{v}$ \\
\hline 72. & $\begin{array}{l}\text { Patrick } \\
\text { NagEl }\end{array}$ & Madness & $\mathrm{v}$ & \\
\hline 73. & $\begin{array}{l}\text { Tami } \\
\text { Koestomo }\end{array}$ & $\begin{array}{l}\text { Riding the tiger of Muslim radicals and egoistical } \\
\text { dissatisfied elite political figures that do not really have } \\
\text { the interests of the Indonesian people at heart is very, very } \\
\text { dangerous. Watch out, Anies Baswedan and Sandiaga } \\
\text { Uno, lest you be devoured alive. }\end{array}$ & $\mathrm{v}$ & \\
\hline 74. & $\begin{array}{l}\text { Maurice } \\
\text { Gold }\end{array}$ & $\begin{array}{l}\text { When the end justifies the means, and Islamism for its } \\
\text { own sake permits everything and anything for its own } \\
\text { glorification, then this is what happens. When Islamist } \\
\text { clerics get political, and use mosques and other venues as } \\
\text { centres of murderously-inclined xenophobic sermons, and } \\
\text { when uneducated Indonesians hear these messages of } \\
\text { hatred emanating from their supposed allah-direct } \\
\text { communication-representatives, and not knowing any } \\
\text { better, who else would they vote for? I have heard that } \\
\text { Indonesian law frowns on the use of houses of worship for } \\
\text { politicisation and rabble-rousing }\end{array}$ & $\mathrm{v}$ & \\
\hline \multicolumn{3}{|c|}{ Total } & 53 people & 21 people \\
\hline
\end{tabular}

